\title{
Livestock water productivity: feed resourcing, feeding and coupled feed-water resource data bases
}

\author{
Michael Blümmel $^{\mathrm{A}, \mathrm{F}}$, Amare Haileslassie ${ }^{\mathrm{B}, \mathrm{D}}$, Anandan Samireddypalle $^{\mathrm{C}}$, Vincent Vadez $^{\mathrm{D}}$ \\ and An Notenbaert ${ }^{\mathrm{E}}$ \\ A International Livestock Research Institute (ILRI), c/o ICRISAT, Patancheru 502324, AP, India. \\ ${ }^{B}$ International Livestock Research Institute and International Crops Research Institute for the Semi Arid Tropics \\ (ICRISAT), Patancheru 502324, AP, India. \\ CInternational Livestock Research Institute (ILRI), c/o IITA, Ibadan, Nigeria. \\ DInternational Crops Research Institute for the Semi Arid Tropics (ICRISAT), Patancheru 502324, AP, India. \\ EInternational Centre for Tropical Agriculture (CIAT), PO Box 823, 00621 Nairobi, Kenya. \\ ${ }^{\mathrm{F}}$ Corresponding author. Email: m.blummel@cgiar.org
}

\begin{abstract}
While water requirement for livestock is widely perceived as daily drinking water consumption, $\sim 100$ times more water is required for daily feed production than for drinking water. Increasing livestock water productivity can be achieved through increasing the water-use efficiency (WUE) of feed production and utilisation. The current paper briefly reviews water requirements for meat and milk production and the extent of, and reason for, variations therein. Life-cycle analysis (LCA) can reveal these variations in WUE but LCA are not tools that can be employed routinely in designing and implementing water-use-efficient feed resourcing and feeding strategies. This can be achieved by (1) choosing agricultural by-products and crop residues where water applications are partitioned over several products for example grain and straw (or food and fodder) contrary to planted forage production where water and land have to be exclusively allocated to fodder production, (2) select and breed WUE crops and forages and exploit cultivar variations, (3) increase crop productivity by closing yield gaps; and (4) increase per animal productivity to reduce the proportion of feed (and therefore water) allocated for maintenance requirement rather than productive purposes. Feed-mediated WUE of dairy buffalo production on almost completely (94\%) by-product-based feeding systems could be reduced from 2350 to $548 \mathrm{~L}$ of water per kg of milk by the combined effect of increasing basal ration quality in a total mixed ration, which resulted in increased milk yield of $\sim 30 \%$, and by increasing crop productivity from $1 \mathrm{t}$ (actual crop yield) to $3 \mathrm{t}$ (potential crop yield). Exemplary, multi-dimensional sorghum improvement using staygreen quantitative trait loci (QTL) introgression for concomitant improvement of WUE of grain and stover production and stover fodder quality showed opportunities for further linked improvement in WUE of crop and livestock production. Metabolisable energy (ME) yield under water stress conditions measured in lysimeters, (which measure crop water transpired) ranged QTL dependent from 16.47 to $23.93 \mathrm{MJ} \mathrm{ME} \mathrm{per} \mathrm{m}^{3} \mathrm{H}_{2} \mathrm{O}$. This can be extrapolated to 8.23-11.97 MJ ME per $\mathrm{m}^{3} \mathrm{H}_{2} \mathrm{O}$ evapotranspired under field conditions. To mainstream improvement in WUE of feed resourcing and feeding, the paper suggests the combination of feed resource databases with crop-soil-meteorological data to calculate how much water is required to produce the feed at the available smallest spatial scale of crop-soil-meteorological data available. A framework is presented of how such a tool can be constructed from secondary datasets on land use, cropping patterns and spatially explicit crop-soil-meteorological datasets.
\end{abstract}

Additional keywords: agricultural by-products, environmental sustainability, resource-use efficiencies.

Received 29 May 2014, accepted 30 June 2014, published online 19 August 2014

\section{Introduction}

Agriculture is the largest consumer of water, accounting for $72 \%$ of total water use (Steinfeld et al. 2006). As demand for industry, municipal and other water uses increase, less water will be available for agriculture and food production, despite increasing food demand, specifically for animal-sourced food (Delgado et al. 1999). Production of food needs to be increased and the water-use efficiencies (WUE) of food production need to be improved, and scope for this exists (Comprehensive Assessment of Water Management in Agriculture 2007). Water requirements for food production can vary widely; for example, for plant-sourced food from $0.5 \mathrm{~m}^{3} / \mathrm{kg}$ potato to $3 \mathrm{~m}^{3} / \mathrm{kg}$ rice and for animal-sourced food from $3.5 \mathrm{~m}^{3} / \mathrm{kg}$ in broiler production to $100 \mathrm{~m}^{3} / \mathrm{kg}$ in beef production, with directly plant-sourced food such as grains and vegetables usually produced in more water-use-efficient ways (Pimentel et al. 
1997). High water requirements are intuitively often connected with very intensive systems, but extensive systems are generally less effective relative to the amount of agricultural output from water input (Zwart and Bastiaanssen 2004). Singh et al. (2004) drew attention to the sometimes surprisingly high water needs for extensive dairy production in India, calculating that in the state of Gujarat, the heartland of the 'white revolution' (widespread increase in milk production), an average of $3.4 \mathrm{~m}^{3}$ of water is required for the production of $1 \mathrm{~kg}$ of milk. The global average is $0.9 \mathrm{~m}^{3}$ and the authors traced high water needs to feed resourcing and production, concluding that on average $10000 \mathrm{~L}$ of water was required to produce the daily feed for one single dairy animal. Conventionally, the relationship between livestock and water is associated with drinking water requirements and the fact that much more water is required for evapotranspiration in feed production still escapes the awareness of many livestock nutritionists. They rarely include water requirement assessments in feed resourcing and ration design.

Blümmel et al. (2009) revisited the data of Singh et al. (2004) and calculated that the amount $(\mathrm{kg})$ of planted forage in the ration was positively correlated $(P=0.014)$ with the amount of water required for the production of $1 \mathrm{~kg}$ of milk, explaining $66 \%$ of the variation in this relationship. A model combining the amount of concentrate fed in a multiple regression with the amount of planted fodder fed explained $82 \%$ of the variation in water needs per unit of milk $\left(\mathrm{L} \mathrm{H}_{2} \mathrm{O} / \mathrm{L}\right.$ of milk $=-191+265 \times$ planted fodder $-433 \times$ concentrate $)$. In planted forage production all water used has to be exclusively allocated to this specific feed resource, in contrast in agroindustrial by-products such as bran and oil cakes and crop residues such as straw, stover and haulms water is partitioned across primary and secondary products. At comparable livestock productivity levels, by-product-based feeding systems are inherently more WUE than feeding systems based on planted forages or primary crop products. The present paper investigates several approaches to improve the WUE of livestock production. This can be achieved by (1) choosing agricultural by-products and crop residues and combining them in livestock nutritionally well balanced rations, (2) selecting and breeding WUE crops and exploit cultivar variations, (3) increasing crop productivity by closing yield gaps, and (4) increasing per animal productivity to reduce the proportion of feed (and therefore water) allocated for maintenance rather than productive purposes.

\section{By-product-based feeding systems: reinforcing effects of intensification of livestock and crop production on increasing livestock water productivity}

\section{Selection of superior basal diet components and targeted supplementation}

Key by-product feed resources are agro-industrial by-products and crop residues with the latter being of particular importance in developing and emerging countries where they commonly account as the single most important fodder resource (Blümmel et al. 2012). Worldwide total crop residue production is estimated at 3.8 billion metric tonnes, with cereals contributing $74 \%$, sugar crops $10 \%$, legumes $8 \%$, tubers $5 \%$ and oil crops $3 \%$ (Lal 2005). Crop residues are generally considered to be of low nutritive quality, but this statement implicitly relates to cereal residues, since leguminous residues can have excellent fodder quality (Prasad et al. 2010). The widespread availability of crop residues and the extent of their use as livestock fodder mark them as a strategic feed resource of the highest order. Furthermore, it is important to realise that crop residues are among the few feed resources that do not need a specific allocation of water (and land for that matter), because the crops are grown largely, though not exclusively, for the production of the primary products of grains and pods. However, in this context it is interesting to note that the monetary value of crop residue relative to grain is getting narrower and in sorghum stover and grain in India have now reached approximately parity (Sharma et al. 2010).

Until recently crop residue fodder traits were largely ignored in crop improvement, although farmers and fodder traders were well aware of differences in the fodder quality of crop residues even within the same species (Kelley et al. 1996). Blümmel and Parthasarathy Rao (2006) surveyed major sorghum stover traders supplying urban and periurban dairy producers around Hyderabad in rain-fed India from 2004 to 2005 and observed that a difference of $5 \%$ points in in vitro digestibility (47\% vs $52 \%$ ) between the poorest- and highest-quality sorghum stover was associated with a price premium of more than $25 \%$. In collaboration with the commercial feed processor Miracle Feed and Fodder Pvt (Shah 2007), which marketed a total mixed ration (TMR) feed block consisting of $94 \%$ of crop residues and agro-industrial by-products (see also Table 1), experimental feed blocks were produced using the poorer- (47\% digestibility) and higher-quality

Table 1. Ingredients of a total mixed ration (TMR) feed block and crude protein (CP) and metabolisable energy (ME) of TMR based on two different sorghum stover and voluntary feed intake (VFI) and milk potential of dairy buffalo fed the two TMR

\begin{tabular}{lclcc}
\hline Ingredient & $\%$ & & TMR composition and response of dairy buffalo \\
\hline Sorghum stover & 50 & & TMR stover 47\% & TMR stover 52\% \\
Bran/husk/hulls & 18 & CP $(\%)$ & 17.1 & 17.2 \\
Oilcake & 18 & ME (MJ/kg) & 7.37 & 8.46 \\
Molasses & 8 & VFI (kg/day) & 18.0 & 19.7 \\
Grain & 4 & VFI (g/kg liveweight) & 33 & 36 \\
Minerals, vitamin, urea & 2 & Milk potential (kg/day) & 9.9 & 15.5 \\
\hline
\end{tabular}


(52\% digestibility) sorghum stover and tested with a commercial dairy buffalo producer (Anandan et al. 2010).

Several important conclusions can be drawn from this work. Very importantly, an intuitively small difference in basal ration digestibility (here sorghum stover) of 5\% points can result in an increase in milk yield of more than $5 \mathrm{~kg}$ per animal per day by the accumulative effects of higher ration metabolisable energy (ME) and higher intake (Table 1). Second, an almost completely by-product-based ration can support milk yields of close to $16 \mathrm{~kg}$ of milk, which is about thrice the Indian average (Blümmel et al. 2013a). These are respectable levels of livestock performance and these data were obtained with dairy buffalo, which have very high milk fat contents ( $\sim 7 \%$ in the cited work) and extrapolation of these data to dairy cattle suggests a potential daily milk yield of up to $20 \mathrm{~kg}$ on almost completely by-product-based rations.

The findings presented in Table 1 also have implications for livestock water productivity. Using average Indian crop yields, harvest indices and conversion factors for primary product to by-product such as oilcakes, bran and molasses, total water requirements to produce one TMR feed block of $15 \mathrm{~kg}$ was estimated at $19.39 \mathrm{~m}^{3}$ (Table 2). Daily milk yields of 15.5 and $9.9 \mathrm{~kg}$ will then require 25.47 and $23.27 \mathrm{~m}^{3}$ of total $\mathrm{H}_{2} \mathrm{O}$ and 1643 and $2350 \mathrm{~L}$ of $\mathrm{H}_{2} \mathrm{O}$ per kg of milk, respectively. Considering the substantially different WUE per unit milk produced, attributing the same water requirement $\left(19.39 \mathrm{~m}^{3}\right)$ to both TMR feed blocks is not convincing. In other words, feedrelated WUE expressed on biomass and/or dry matter (DM) yield, contain limited information. Actual milk yields (or general animal performance) will not be known when designing rations and planning new feeding regimes but animal nutritionists will use ME and protein values and intake predictions to calculate prospective and targeted animal performances. WUE for feed production can then be expressed relative to $\mathrm{ME}$ and in the case discussed here 153 and $175 \mathrm{~L}$ of $\mathrm{H}_{2} \mathrm{O}$ are required to produce $1 \mathrm{MJ}$ ME in TMR feed blocks with higher and poorer quality sorghum stover, respectively.

Expressing water requirement relative to ME content/yield (and/or protein content for that matter in high protein feedstuffs) seems a good choice avoiding the shortfalls of computing mere biomass yield per unit water input while still offering the possibility of estimating financial water use efficiencies from the calculation of prospective and targeted animal performance and its financial value (see also below).

Table 2. Water requirements for total mixed ration (TMR) ingredients and for TMR feed block

$\mathrm{n} / \mathrm{a}$, not applicable; $\mathrm{n} / \mathrm{c}$, not calculated

\begin{tabular}{lrcc}
\hline Ingredient & $\%$ & $\begin{array}{c}\text { kg of ingredient } \\
\text { per } \mathrm{m}^{3} \text { of } \mathrm{H}_{2} \mathrm{O}\end{array}$ & $\begin{array}{c}\mathrm{m}^{3} \text { of } \mathrm{H}_{2} \mathrm{O} \text { per } 15 \mathrm{~kg} \\
\text { TMR }\end{array}$ \\
\hline Sorghum stover & 50 & 0.70 & 10.71 \\
Bran/husks/hulls & 18 & 0.67 & 4.03 \\
Oilcakes & 18 & 0.52 & 1.404 \\
Molasses & 8 & 5.2 & 1.56 \\
Grains & 4 & 2.8 & 1.68 \\
Minerals, vitamins, urea & 2 & $\mathrm{n} / \mathrm{c}$ & $\mathrm{n} / \mathrm{c}$ \\
Total & 100 & $\mathrm{n} / \mathrm{a}$ & 19.39 \\
\hline
\end{tabular}

This difference in WUE relative to ME (153 vs $175 \mathrm{~L}$ of $\mathrm{H}_{2} \mathrm{O}$ ) is smaller than the WUE expressed relative to milk produced (1643 vs $2350 \mathrm{~L}$ of $\mathrm{H}_{2} \mathrm{O}$ ) because the water to feed ME relationship does not capture the intensification effects of higher feed quality that translates also into higher feed intake and a shift in feed utilisation from maintenance to production (Blümmel et al. 2013a). In case of the milk productivity and water requirement data reported in Tables 1 and 2, at $10 \mathrm{~kg}$ of milk per day about $50 \%$ of the water would need to be allocated for feed maintenance requirement, decreasing to less than $30 \%$ at $15 \mathrm{~kg}$ per day. In contrast, at $3 \mathrm{~kg}$ of milk daily more than $70 \%$ of the water is used for feed maintenance requirements (calculated from Blümmel et al. 2013a). It is therefore important to realise that intensification of crop production would contribute immensely to livestock water productivity. For example water requirements used in Table 2 were based on actual (low) average crop yields in small farmers' fields in India. The yield gaps under those conditions are estimated at $\sim 1: 3$, in other words adoption of rather simple management options such as timely planting and weeding, and fertiliser application, could triple crop yields. This would reduce water requirements for the above described TMR to $\sim 6.46 \mathrm{~m}^{3}$ per block and water requirement per $\mathrm{kg}$ of milk to between 548 and 783 L. To conclude, concomitant intensification of crop and livestock production will have hugely beneficial effects on livestock water productivity measured as agricultural and livestock output per unit water. These relationships need to be compared and aligned with an economic assessment looking at $\$ \mathrm{US} / \mathrm{m}^{3} \mathrm{H}_{2} \mathrm{O}$ input and output. It also important to note that livestock outputs entail less tangible and quantifiable products such as draught power, manure and a range of social services, which will need to be included into truly comprehensive livestock water productivity analysis (Peden et al. 2007; Descheemaeker et al. 2010; Haileslassie et al. 2011).

In East Africa, Descheemaeker et al. (2011) and Gebreselassie et al. (2009) reported livestock water productivity values ranging between US\$0.01 and US\$0.4 $\mathrm{m}^{-3} \mathrm{H}_{2} \mathrm{O}$. The least efficient value was calculated for a local low-productive animal while the higher value was for both improved genetics (cross-bred) and feed. When converted into financial water productivity, the results reported in Table 2 translate into US\$0.28 and US $\$ 0.41 \mathrm{~m}^{-3} \mathrm{H}_{2} \mathrm{O}$ for TMR $47 \%$ and $52 \%$, respectively. In other words, in production- and market-oriented systems in East Africa (cross-bred animals) and India (dairy buffalos) livestock water productivity when expressed as US\$ return per water input broadly showed similar ranges.

\section{Improving fodder value and WUE of basal diets concomitantly by multi-dimensional crop improvement}

The findings presented and discussed in Tables 1 and 2 demonstrate that apparently small differences in fodder quality of basal rations (here sorghum stover) can have a significant impact on livestock production and livestock water productivity. The magnitude of difference i.e. $~ 5 \%$ points in digestibility and more was found in straw, stover and haulms of a range of cereal and leguminous crops (Sharma et al. 2010; Blümmel et al. 2012, $2013 b$ ). These differences can be exploited by simply phenotyping for crop residue fodder quality during multi- 
dimensional crop improvement (Sharma et al. 2010; Blümmel et al. 2012, 2013b). These phenotypings essentially detected cultivar-dependent variations in crop residue fodder quality traits, which were largely unintended and which came about by chance. However, crop residue fodder traits can also be actively improved by targeted genetic enhancement, using conventional (Bidinger et al. 2010; Ertiro et al. 2013; Zaidi et al. 2013) and molecular breeding approaches (Nepolean et al. 2006; Vinayan et al. 2013; ACIAR 2014). In light of the following discussions about feed resource databases below, it is important to point out that these multi-dimensional crop improvement collaborations have strong environmental components. New dual/multi-purpose cultivars are tested across widely different regions and seasons (Blümmel et al. 2010; Ravi et al. 2013) and management conditions (Bidinger and Blümmel 2007; Blümmel et al. 2007), providing potentially very targeted input variables into such feed resource databases as exemplified in Tables 3 and 4 below.

Above-mentioned multi-dimensional crop improvement efforts focussed mainly on increasing grain and pod yield and crop residue yield and fodder quality. As argued by Vadez et al. (2011a), additional traits can be targeted, for example WUE. These authors introgressed 31 sorghum lines with different staygreen quantitative trait loci (QTL) (Vadez et al. $2011 b$; ACIAR 2014) and suggested that staygreen introgression may concomitantly improve WUE and stover fodder quality. Blümmel and colleagues (ACIAR 2014) investigated the same sorghum lines for a range of fodder

Table 3. Summary of feed supply and demand in India, drawn from information published by NIANP (2003)

\begin{tabular}{|c|c|c|}
\hline & $\begin{array}{c}\text { Feed resource } \\
\left(10^{6} \mathrm{t}\right)\end{array}$ & $\begin{array}{c}\text { Feed resource } \\
(\%)\end{array}$ \\
\hline \multicolumn{3}{|c|}{ Greens } \\
\hline From forest area & 89.37 & 4.5 \\
\hline From fallow lands & 23.21 & 1.2 \\
\hline $\begin{array}{l}\text { From permanent pastures } \\
\text { and grazing areas }\end{array}$ & 28.70 & 1.4 \\
\hline $\begin{array}{l}\text { From cultivable waste lands } \\
\text { and miscellaneous tree crops }\end{array}$ & 17.51 & 0.9 \\
\hline \multirow[t]{2}{*}{ From planted fodder crops } & 303.26 & $\underline{15.1}$ \\
\hline & & $\overline{23.0}$ \\
\hline \multicolumn{3}{|c|}{ Crop residues } \\
\hline Coarse & 154.83 & 27.8 \\
\hline Fine straw & 194.11 & 34.8 \\
\hline \multirow[t]{2}{*}{ Leguminous straw } & 44.44 & $\underline{8.0}$ \\
\hline & & $\overline{70.6}$ \\
\hline \multicolumn{3}{|c|}{ Concentrates } \\
\hline Oil cakes & 15.76 & 2.8 \\
\hline Brans & 13.29 & 2.1 \\
\hline Grains for feeding livestock & 5.74 & 1.0 \\
\hline \multirow[t]{2}{*}{ Chunnis (leguminous husks, hulls etc) } & 0.53 & $\underline{0.1}$ \\
\hline & & $\overline{6.3}$ \\
\hline \multicolumn{3}{|c|}{ Feed/nutrient requirements versus feed availability } \\
\hline \multicolumn{3}{|c|}{$\begin{array}{r}\text { Deficit (\%) } \\
\text { Detar }\end{array}$} \\
\hline DM & \multicolumn{2}{|c|}{6.0} \\
\hline Digestible crude protein & \multicolumn{2}{|c|}{61.0} \\
\hline Total digestible nutrients & \multicolumn{2}{|c|}{50.0} \\
\hline
\end{tabular}

quality traits and the relationships between stover ME content and stover WUE are presented in Fig. $1 a, b$.

Generally, differences in WUE were more expressed under water-stressed than under well watered conditions. This was because the physiological traits underlying the QTL had mostly an effect under water-limited conditions. Among the three highest WUE, that is kilogram of stover produced per $\mathrm{m}^{3}$ $\mathrm{H}_{2} \mathrm{O}$, stover ME per kg stover varied dependent on sorghum line by $\sim 1$ MJ (Fig $1 a, b$ ), which is of a similar order to the ME difference observed in the two TMR feed blocks described and tested in Table 1. In addition, WUE in sorghum stover in Fig. $1 a, b$ can be several-fold higher than that of stover used for the TMR WUE calculations $\left(0.70 \mathrm{~kg} / \mathrm{m}^{3} \mathrm{H}_{2} \mathrm{O}\right)$. It should be noted here that the calculations of WUE from Figs 1 and 2 are coming from lysimetric assessment of WUE, where most of the component of soil evaporation is prevented by covering the soil surface with a plastic sheet and plastic beads (Vadez et al. 2011a, 2011b). Therefore, WUE was calculated and presented on the basis of crop water transpiration and not on the basis of crop evapotranspiration. If we consider the evapotranspiration of the crop to have been about twice that of the crop transpiration, the WUE data of Fig. $1 a, b$ should be divided by a factor of two to be comparable to field estimates of crop WUE. When the sorghum lines were grouped for staygreen QTL they were introgressed with, under well watered conditions WUE for whole-plant production (i.e. grain and stover) ranged from 3.76 to $4.76 \mathrm{~kg} / \mathrm{m}^{3} \mathrm{H}_{2} \mathrm{O}$, for stover production from 2.52 to $2.80 \mathrm{~kg} / \mathrm{m}^{3} \mathrm{H}_{2} \mathrm{O}$, with stover $\mathrm{ME}$ production ranging from 18.37 to $21.4976 \mathrm{MJ} \mathrm{ME} / \mathrm{m}^{3} \mathrm{H}_{2} \mathrm{O}$ (see Fig. 2).

Under water-stressed conditions, WUE for whole-plant production ranged from 3.82 to $4.54 \mathrm{~kg} / \mathrm{m}^{3} \mathrm{H}_{2} \mathrm{O}$, for stover production from 2.3 to $3.43 \mathrm{~kg} / \mathrm{m}^{3} \mathrm{H}_{2} \mathrm{O}$, with stover $\mathrm{ME}$ production ranging from 16.47 to $23.93 \mathrm{MJ} \mathrm{ME} / \mathrm{m}^{3} \mathrm{H}_{2} \mathrm{O}$ (see Fig. 3).

In crop physiology, the definition of WUE is in fact inverse to the evaporative demand (Bierhuizen and Slatyer 1965), such that transpiration efficiency, which is higher for $\mathrm{C}_{4}$ than for $\mathrm{C}_{3}$ crops. Therefore, as a first cut, the water productivity of residues from $\mathrm{C}_{3}$ crops such as wheat or rice would be lower than the water productivity of crops such as sorghum or maize. As another criterion to differentiate scenarios, the water productivity of residue would be higher if crops are grown under conditions of low evaporative demand. Beyond these cardinal crop and growth condition factors affecting the water productivity of feed resources, there exists a lot of genetic variability for water productivity within these cardinal factors (see a recent review by Vadez et al. 2014). Another important factor driving the water productivity of crop is the evaporative demand prevailing at the location and timing of production. Therefore, taken together, there is room to synergistically enhance water productivity of feed, playing on crops, growth conditions, and cultivars.

\section{Approaches for complementing feed resource databases by water requirements}

\section{Feed database requirements and possible structures}

Complementing feed resource databases by data about the amount of water required to produce them consists of two 
Table 4. Subclasses of feed resources, their metabolisable energy content (ME, MJ/kg), assumption and spatial units Feed subclasses and assumption were extracted from the NIANP 2003 database

\begin{tabular}{|c|c|c|c|c|}
\hline & ME mean ${ }^{\mathrm{A}}$ & $\mathrm{ME}_{\text {range }} \mathrm{A}^{\mathrm{A}}$ & Assumption & Spatial units \\
\hline \multicolumn{5}{|c|}{ Greens } \\
\hline Cultivable wasteland & - & - & Total area, $1 \mathrm{t} / \mathrm{ha}$ & Village \\
\hline Current fallows & - & - & Total area, $1 \mathrm{t} / \mathrm{ha}$ & $\downarrow$ \\
\hline Forests & - & - & $50 \%$ of area accessible, $3 \mathrm{t} / \mathrm{ha}$ & Taluk \\
\hline Miscellaneous trees & - & - & Total area, $1 \mathrm{t} / \mathrm{ha}$ & $\downarrow$ \\
\hline Other fallows & - & - & Total area, $1 \mathrm{t} / \mathrm{ha}$ & Mandal \\
\hline Permanent pasture & 7.54 & $6.64-8.39$ & Total area, $5 \mathrm{t} / \mathrm{ha}$ & $\downarrow$ \\
\hline Cultivated forages crops: & & & $4 \%$ of cropped area, $40 \mathrm{t} / \mathrm{ha}$ & District \\
\hline Legumes & 8.21 & $7.75-8.79$ & - & \\
\hline Grass & 7.71 & $6.84-8.91$ & - & \\
\hline \multicolumn{5}{|c|}{ Crop residues } \\
\hline \multicolumn{5}{|l|}{ Coarse straw } \\
\hline Sorghum (kharif season) & 6.72 & $5.16-7.95$ & Harvest index 0.29 & \\
\hline Sorghum (Rabi season) & 7.63 & $6.28-9.10$ & Harvest index 0.29 & \\
\hline Pearl millet & 5.98 & $3.37-8.89$ & Harvest index 0.29 & \\
\hline Barley & 6.63 & $6.37-6.76$ & Harvest index 0.44 & \\
\hline Maize & 7.22 & $6.10-8.08$ & Harvest index 0.29 & \\
\hline Oats & 7.85 & $7.00-8.65$ & Harvest index 0.33 & \\
\hline Smaller millet & 7.39 & $7.07-7.99$ & Harvest index 0.29 & Village \\
\hline Other cereals & - & - & Harvest index 0.33 & $\downarrow$ \\
\hline Sugarcane tops & - & - & Harvest index 0.25 & $\begin{array}{c}\text { Taluk } \\
\downarrow\end{array}$ \\
\hline Fine straw & & & & Mandal \\
\hline Rice & - & $4.28-8.55$ & Harvest index 0.44 & $\downarrow$ \\
\hline Wheat & - & $4.51-8.02$ & Harvest index 0.50 & District \\
\hline Finger millet & - & $7.07-7.99$ & Harvest index 0.33 & \\
\hline \multicolumn{5}{|l|}{ Legume straw } \\
\hline Groundnut & 8.34 & $5.61-10.43$ & Harvest index 0.37 & - \\
\hline Chickpea & 7.74 & $4.45-9.32$ & Harvest index 0.37 & \\
\hline Black lentil & 8.32 & $7.40-9.25$ & Harvest index 0.37 & \\
\hline Mung bean & 8.27 & $7.68-9.10$ & Harvest index 0.37 & \\
\hline Pigeon pea & 7.73 & $7.22-8.48$ & Harvest index 0.37 & \\
\hline Soybean & 8.32 & $7.40-9.25$ & - & \\
\hline Cowpea & 8.46 & $7.82-9.19$ & - & \\
\hline \multirow[t]{2}{*}{ Lablab } & 8.22 & $7.10-9.12$ & - & \\
\hline & & \multicolumn{3}{|l|}{ Concentrates } \\
\hline Grains & & & & \\
\hline Pearl millet grain & 10.98 & $10.39-1142$ & 0.05 of total grain production & \\
\hline Barley grain & - & - & 0.10 of total grain production & \\
\hline Maize grain & 13.08 & $12.11-13.83$ & 0.10 of total grain production & \\
\hline Oat grain & - & - & 0.10 of total grain production & \\
\hline Other cereal grain & - & - & 0.10 of total grain production & \\
\hline Rice grain & - & - & 0.02 of total grain production & \\
\hline Wheat grain & - & - & 0.02 of total grain production & \\
\hline Sorghum grain & 13.14 & $12.81-13.71$ & 0.05 of total grain production & \\
\hline Small millets (teff) & 10.90 & $10.72-11.10$ & 0.10 of total grain production & \\
\hline Cakes & & & & Village \\
\hline Coconut cake & - & - & 0.63 of nut yield & $\downarrow$ \\
\hline Cotton cake & 7.65 & $5.92-9.41$ & 0.50 of seed yield & Taluk \\
\hline Groundnut cake & 8.32 & $7.67-8.98$ & 0.70 of seed yield & $\downarrow$ \\
\hline Linseed cake & - & - & 0.70 of seed yield & Mandal \\
\hline Niger cake & - & - & 0.70 of seed yield & $\downarrow$ \\
\hline Rape and mustard cake & 10.67 & $10.49-10.86$ & 0.70 of seed yield & District \\
\hline Sunflower cake & - & - & 0.70 of seed yield & \\
\hline Safflower cake & - & - & 0.70 of seed yield & \\
\hline Sesame cake & 10.53 & $10.33-10.72$ & 0.70 of seed yield & \\
\hline
\end{tabular}


Table 4. (continued)

\begin{tabular}{|c|c|c|c|c|}
\hline & ME mean ${ }^{\mathrm{A}}$ & ME range $^{\mathrm{A}}$ & Assumption & Spatial units \\
\hline \multicolumn{5}{|c|}{ Bran } \\
\hline Maize bran & 9.16 & $7.68-10.51$ & 0.08 of grain yield & \\
\hline Millet bran & 8.94 & $7.63-9.89$ & 0.08 of grain yield & \\
\hline Rice bran & - & - & 0.08 of grain yield & \\
\hline Wheat bran & 11.20 & $10.93-11.46$ & 0.08 of grain yield & \\
\hline \multicolumn{5}{|c|}{ Pulse husk/pod } \\
\hline Chickpea pods/husk & 8.82 & $8.74-8.95$ & 0.03 of grain & \\
\hline Black lentil pods/husk & - & - & 0.03 of grain & \\
\hline Mung bean pods/husk & - & - & 0.03 of grain & \\
\hline Moth bean pods/husk & - & - & 0.03 of grain & \\
\hline Pigeon pea pods/husk & 9.11 & $8.94-9.24$ & 0.03 of grain & \\
\hline Other pods/husks & - & - & 0.03 of grain & \\
\hline
\end{tabular}

${ }^{\mathrm{A}} \mathrm{ME}$ values are from ILRI Patancheru database (http://ilrihyd.wikispaces.com, accessed 5 July 2014).

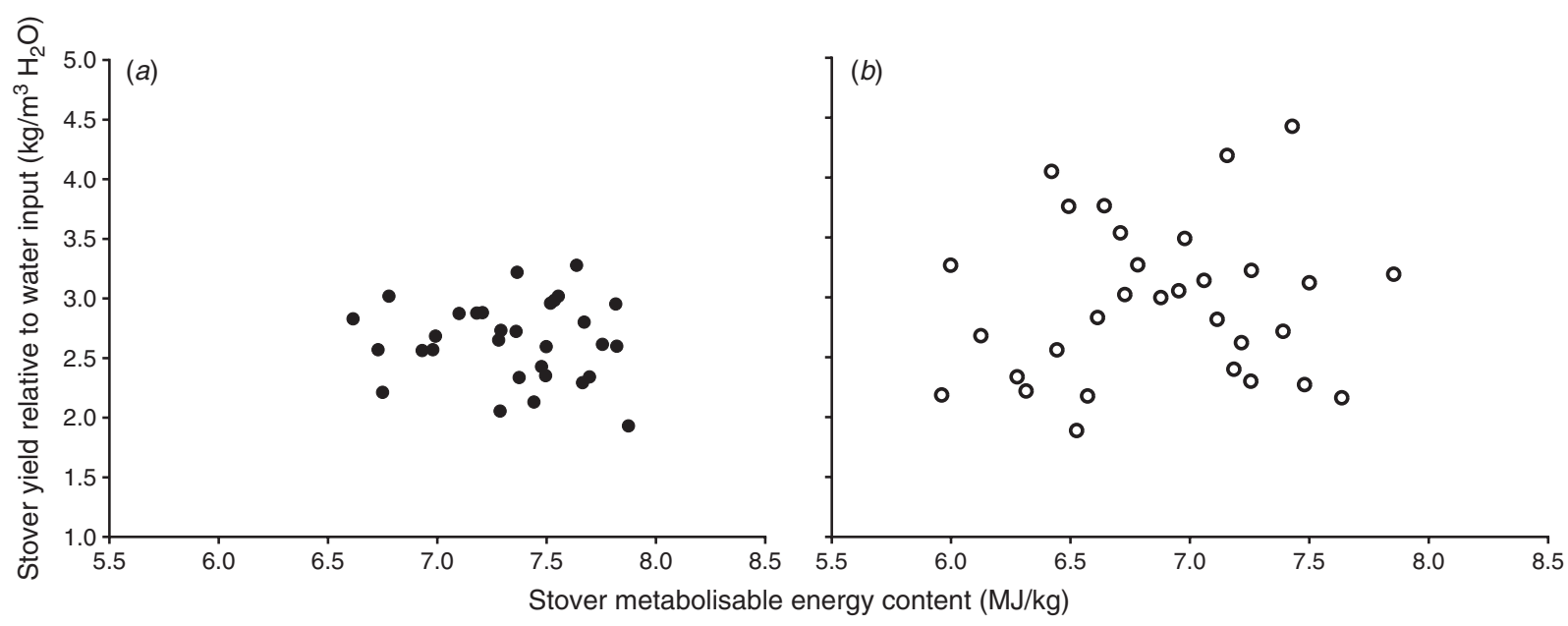

Fig. 1. (a) Stover metabolisable energy content and stover produced from $1 \mathrm{~m}^{3}$ of water under well watered conditions in 31 sorghum lines introgressed with staygreen qualitative trait loci. (b) Stover metabolisable energy content and stover produced from $1 \mathrm{~m}^{3}$ of water under water-stressed conditions in 31 sorghum lines introgressed with staygreen qualitative trait loci.

major steps: (1) constructing a feed database; and (2) propose causal relationships between feed production and water depletion and practical approaches on how to quantify the latter. The estimations of the quantity and quality of feed available and the generation of feed demand-supply scenarios can be tedious and complex, particularly when required baseline data are lacking. To be useful for decision making, they have to be down-scalable, or ideally, to be constructed for small administrative units. It has been suggested that the first steps in constructing a feed database depend mainly on availability of data sources (identification and description of land-use pattern at a sufficiently small scale or for disaggregated administrative units, such as village, district, state or region (NIANP 2003; Ramachandra et al. 2007; van Breugel et al. 2010). The challenge is that few comprehensive country-level datasets about feed supply and demand exist for developing and emerging countries.

As an exception, India has recently systematically quantified countrywide feed demand and supply by coordinated central government and state efforts (NIANP 2003). Major feed classes and their contributions are summarised in Table 3. This survey shows that, on a DM basis, crop residues were the single most important fodder resource, contributing $\sim 71 \%$ to the overall feed resources. The area under planted forage contributed $\sim 23 \%$ and was rather stagnant during the past two decades, increasing merely from $297120000 \mathrm{t}$ in 1986 to $303269000 \mathrm{t}$ in 2003 . Fodder from common property resources, forests, pastures and fallow lands constituted less than $16 \%$ of the available fodder. Also, notable was that concentrates represented a very low proportion $(<7 \%)$ of the available feed resources, and there was no indication of any rapid increase in their use (Table 3). The countrywide gap between feed demand and supply derived from the livestock census was minor for feed quantity (DM) but was large in regard to feed quality, since the estimated annual feed DM deficit was only $6 \%$, while digestible crude protein and total nutrients were estimated to fall short by $61 \%$ and 50\%, respectively (NIANP 2003).

The feed database as summarised in Table 3 would be unsuitable for complementation with water requirement estimates. However, the Indian NIANP database is built up 

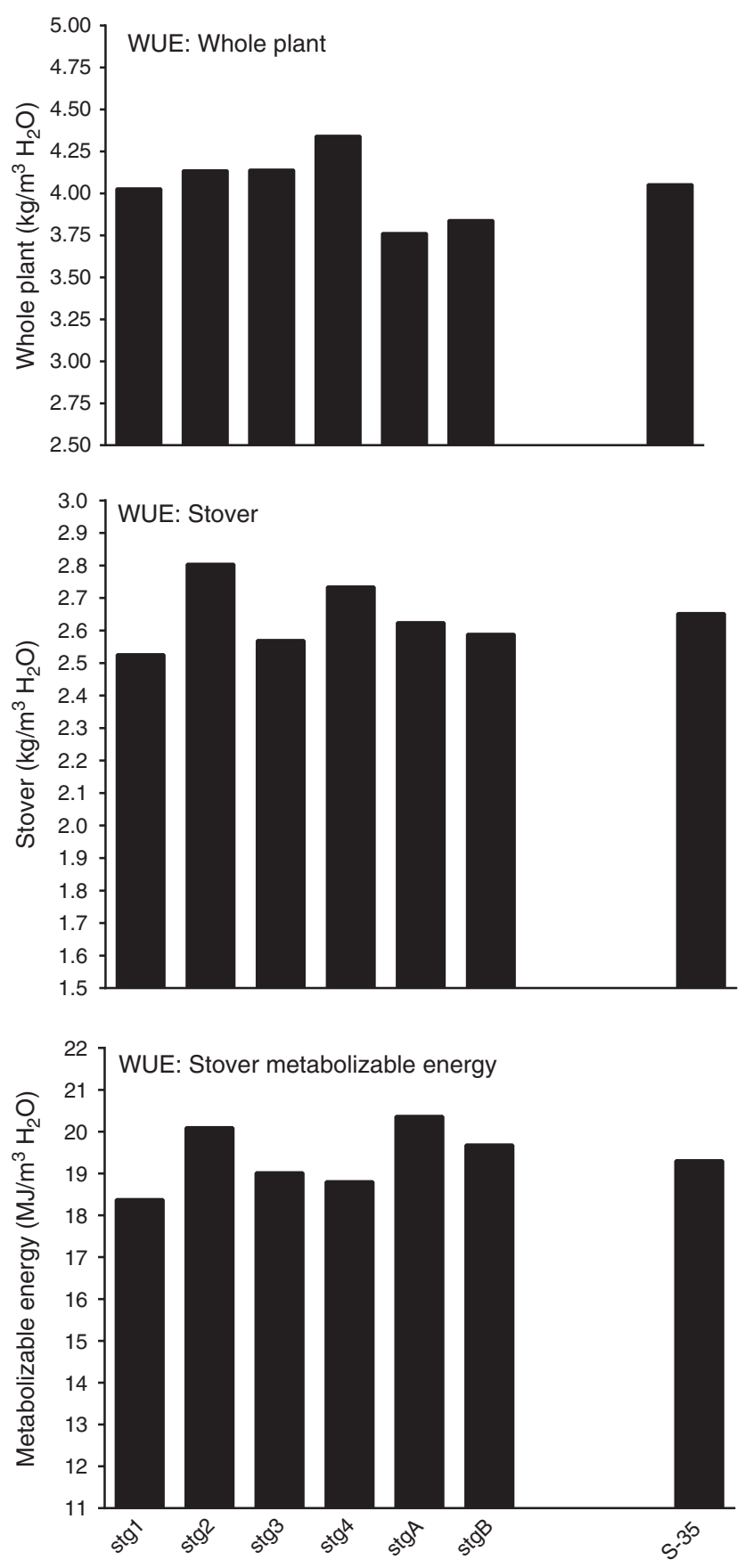

Fig. 2. Staygreen qualitative trait loci-associated water-use efficiencies (WUE) in sorghum background S-35 under well watered conditions.

from very detailed information about specific feed resources (Table 4), starting from village level, although generally presented as aggregations at district levels. If district-level data are considered to be too general, disaggregation is thus possible from District to Mandal to Taluk to Village level. The data are derived from data on land-use and copping pattern. Feed resource availability is then based on these, in combination with assumptions about, for example, yield, crop biomass partitioning into grain, straw, stover, haulms, bran and cake
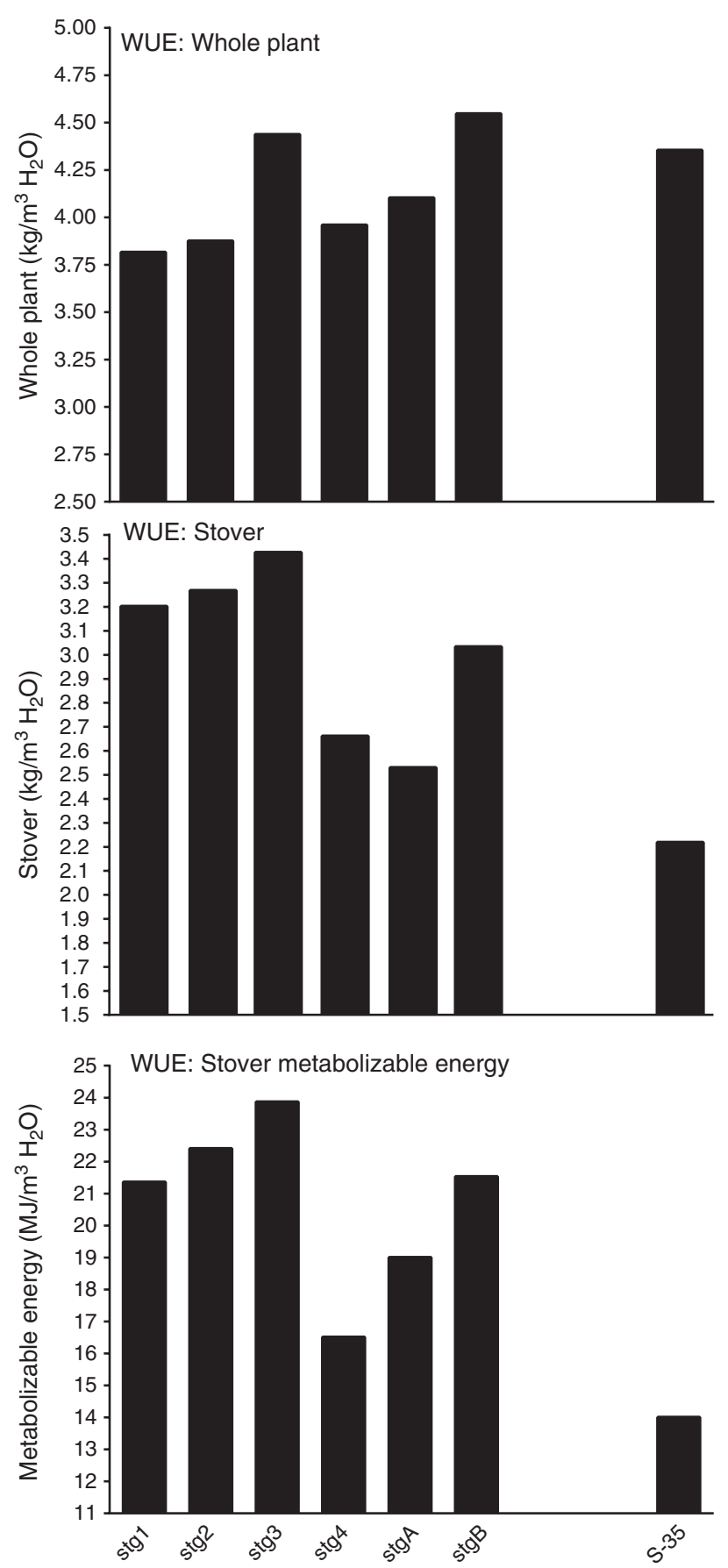

Fig. 3. Staygreen qualitative trait loci-associated water-use efficiencies (WUE) in sorghum background S-35 under water-stressed conditions.

(Table 4). Assumptions about how much of the potential feed resources are actually available for feeding rather than used for competitive purposes such as paper industry and conservation agriculture, are applied. Approximate fodder-quality indices such as digestible crude protein and total digestible nutrients are included at different tiers of the feed database (NIANP 2003; Ramachandra et al. 2007).

The many assumptions and/or constants used are temporary compromises that can act as place holders for more targeted and 
more specific input variables. For example, as described above, much more specific data are generated from multi-dimensional crop improvement and are included in Table 4 as means and ranges in feed and fodder ME. This is in stark contrast to the assumed digestible protein and total digestible nitrogen values in the original NIANP 2003 database, which were almost identical across whole-feed subclasses (values not shown). Substituting feed and fodder trait mean values and constants by more feed source-, crop-, cultivar-, and location-specific values seems a challenge. However, there are related research and extension projects in India (Garg et al. 2013) and elsewhere (FAO 2012) that attempt to describe feed resources, and especially variations in fodder quality and even fodder prices, on scales small enough to provide IT supported farmer-specific ration-balancing programs on a village level. Combining efforts with such projects and global institutions as FAO and using the facilities of IT platforms will make generation of feed databases with more specific and detailed information feasible.

\section{Framework to combine feed-resource databases and water-input requirement estimates}

Estimation of water investment in livestock feed production is data intensive and complex (Peden et al. 2007; Descheemaeker et al. 2010; Haileslassie et al. 2011). Compounding factors include, for example, multiple use of agricultural water, limited knowledge of water productivity on natural pasture, common property resources, forest and extent of use of plant biomass for feeding. However, the major challenges in estimating feed-mediated livestock water productivity lies in defining and describing feed resources and feed usage rather than in estimating water depletion. Once feed resources and feed usage are described in sufficient detail, water depletion for livestock feed production can be estimated from, and linked to, climate, irrigation and soil and crop parameters (Fig. 4). The feed database tool as conceived and constructed by NIANP (2003) provides a perfect starting point. It simply needs to be connected and combined with modules that estimate total evapotranspired water per ha of land use. Ideally, feed resources and evapotranspired water should be matched at the smallest common spatial units from which feed databases are built, such as in the NIANP case villages. However, as outlined in Fig. 4, a range of specific crop-management, soil and meteorological data will be required and the spatial availability of these datasets will determine at which spatial level feed resource-water demand datasets can be constructed. The core information generated by the input variables listed in Fig. 4 is total evapotranspiration in $\mathrm{mm}$ /day by crop/plant type, which needs to be computed for cropspecific growing period and multiplied by a factor of 10 to get the output in $\mathrm{m}^{3}$ /ha per feed-source type [crop type (compare also van Breugel et al. 2010)].

One of the major limitations for the water-requirement calculations remains the availability of good-quality input data. First, the core data on land-use and cropping patterns are limited in many developing countries. Often annual agricultural census data are available by crop type only. The actual crop residue data that goes into the feed database are thus constructed on the basis of harvest indices and other locally developed conversion factors. The data on planted fodder are commonly reported as a percentage of total cropped areas, without details on the fodder crop types and varieties (e.g. Ramachandra et al. 2007) and data on productivity are often lacking. In many developing and emerging countries of the world, green fodder from collecting, grazing or natural pasture, fallow lands and

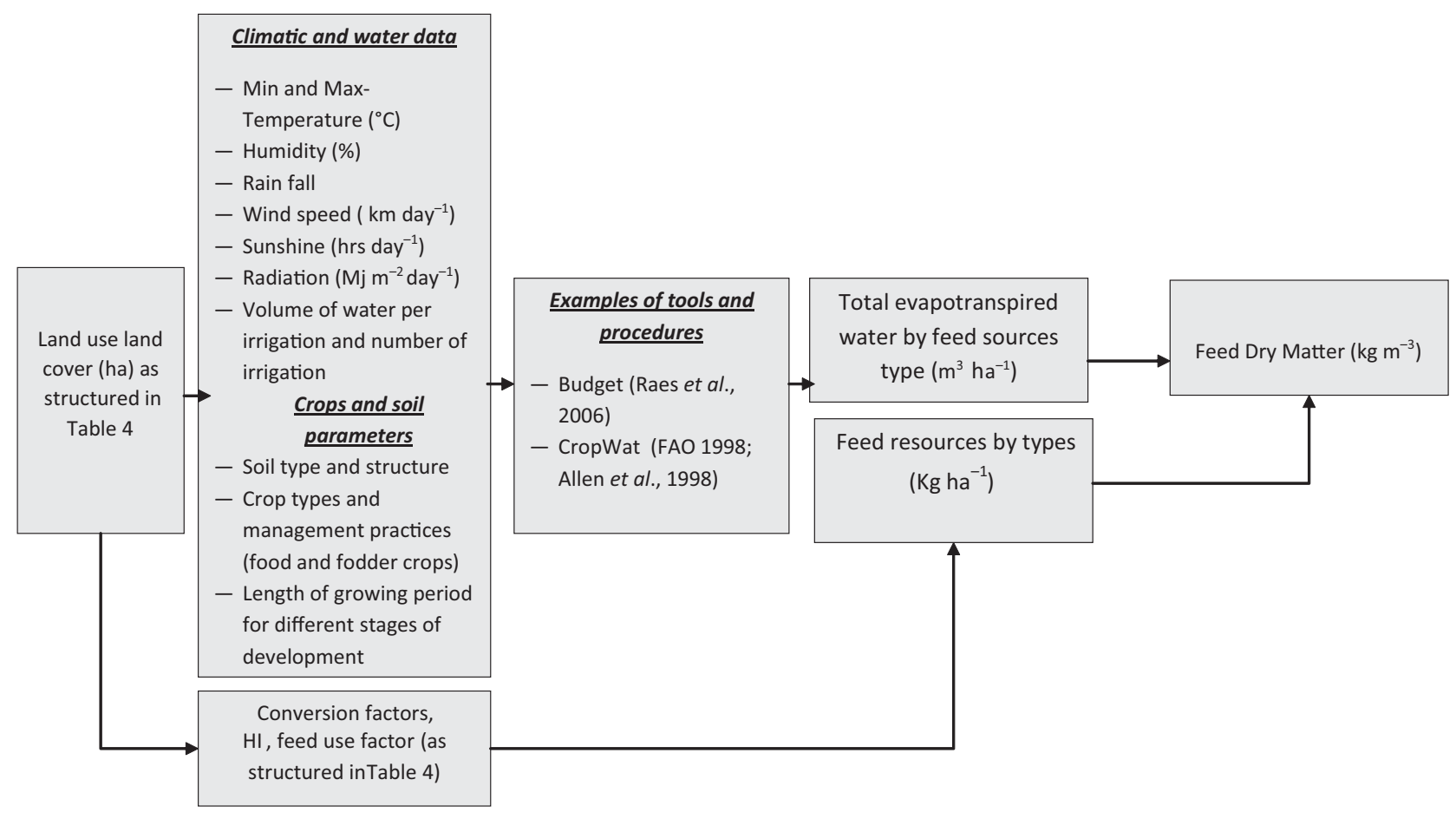

Fig. 4. A simplified framework to combine feed resource database and water-input requirement estimates. 
wastelands constitute an important feed resource. Lack of data on species composition, area extent and productivity are thus major gaps in need of being addressed (Ramachandra et al. 2007). In addition, the conversion values and harvest index (HI) are dynamic in view of ongoing crop diversification and intensification efforts. In brief, feed database information across countries and regions are inconsistent. Investments in innovative approaches toward estimation and standardisation of such variables are thus of paramount importance.

Once the feed database is established, the actual procedures, specification and tools to process and compute effective rainfall and evapotranspiration are well established (e.g. Allen et al. 1998; FAO 1998). As depicted on Fig. 4, data used as input into these tools comprise rainfall and reference evapotranspiration $\left(\mathrm{ET}_{0}\right)$ or detailed climatic parameters to compute $\mathrm{ET}_{0}$. Many countries have a good density of climatic station networks that, with relatively straightforward processing, can provide the necessary input data. There are also a lot of freely available global datasets containing a variety of climate variables. The WorldClim (http://worldclim.org/, accessed 4 July 2014), and CCAFS (http://www.ccafs-climate.org/data/, accessed 4 July 2014) data portals and local climate estimator [LocClim (FAO 2005)], for example, contain information for long-term average, current climate as well as projections for the future. Local relevance and spatial resolution remain important challenges. Cross-checking with the abovementioned climate station data is thus important.

The evaporation power of the atmosphere is expressed by $\mathrm{ET}_{0}$. The $\mathrm{ET}_{0}$ represents the evapotranspiration from a standardised vegetated surface. This needs crops specifications, such as crop coefficients, stress resistance factors and rooting depth, which are available also for major crops from Allen et al. (1998) or already incorporated into these tools; selection of crop of interest suffices to capture these crop-specific values. Validation of these for the local circumstances will be important.

Soil data are also important input to these tools. CropWat, for example, requires a very simplified soil type in terms of its structure (FAO 1998) to compute soil water. Information such as FAO's global soil map or ISRIC's Harmonised World Soil Database can be also explored to capture such soil information. With increasing information technology and worldwide data networking, the opportunities to use relevant and good-quality global or regional datasets are likely to increase. While the geographical information system tools that enable superimposing these on the administrative or agroecological units at which the feed database is collected are already widely available.

Still, concerted action for enhancing livestock water productivity by, for example, linking feed and water resource databases is currently constrained by a lack of both awareness and investments. A conventionally sectorial approach (e.g. feed, water, soil, trees) still dominates, resulting in one-dimensional advice for policy, often with marginal benefit to the development and sustainability agenda. Soft coupling of the water-feed nexus by external models and tools is time consuming, prone to errors and it limits the development of regional and global scenarios from the understanding of local trends. We suggest investing in hard coupling of feed resource databases (e.g. NIANP 2003) with water resource tools (Budget,
CropWat), with crop management-soil-meteorological data being the interface between these two modules.

\section{Conclusions}

Often unrealised, water requirement for feed production is the major taker of water in livestock production, surpassing drinking water requirements by 100 -fold and more. With strongly increasing demand for animal-sourced food in developing and emerging countries, more feed will be required, but this feed needs to be produced in a more water-use-efficient way than is currently the case. By-product feeding based on improved basal feed ingredients and well targeted supplementation will reduce water requirements relative to animal produce. Linked intensification of crop and livestock production will be a major driver for higher feed-mediated WUE in livestock production. To mainstream improvement in WUE of feed resourcing and feeding, feed resource databases should be combined with crop-soil-meteorological data to calculate how much water is required to produce the feed at the available smallest spatial scale of crop-soil-meteorological data availability. A framework is presented of how such a tool can be constructed from secondary datasets on land use, cropping patterns and spatially explicit crop-soil-meteorological datasets.

\section{References}

ACIAR (2014) Final report of CIM/2007/120 project (Improving postrainy sorghum varieties to meet the growing grain and fodder demand in India) - ICRISAT, 2014.

Allen RG, Pereira LS, Raes D, Smith M (1998) 'Crop evapotranspiration. Guidelines for computing crop water requirements.' FAO irrigation and drainage paper 56. (FAO: Rome)

Anandan S, Khan AA, Ravi D, Reddy J, Blümmel M (2010) A comparison of sorghum stover based complete deed blocks with a conventional feeding practice in a peri urban dairy. Animal Nutrition and Feed Technology 10S, 23-28.

Bidinger FR, Blümmel M (2007) Effects of ruminant nutritional quality of pearl millet [Pennisetum glaucum (L) R. Br.] stover. 1. Effects of management alternatives on stover quality and productivity. Field Crops Research 103, 119-128. doi:10.1016/j.fcr.2007.05.006

Bidinger FR, Blümmel M, Hash CT, Choudhary S (2010) Genetic enhancement for superior food-feed traits in a Pearl Millet [Pennisetum glaucum (L.) R. Br.] variety by recurrent selection. Animal Nutrition and Feed Technology 10S, 61-68.

Bierhuizen JF, Slatyer RO (1965) Effect of atmospheric concentration of water vapor and $\mathrm{CO}_{2}$ in determining transpiration-photosynthesis relationships of cotton leaves. Agricultural Meteorology 2, 259-270. doi:10.1016/0002-1571(65)90012-9

Blümmel M, Parthasarathy Rao P (2006) Economic value of sorghum stover traded as fodder for urban and peri-urban dairy production in Hyderabad, India. International Sorghum and Millet Newsletter 47, 97-100.

Blümmel M, Bidinger FR, Hash CT (2007) Management and cultivar effect on ruminant nutritional quality of pearl millet [Pennisetum glaucum (L) R. Br.] stover. Effects of cultivar choice on stover quality and productivity. Field Crops Research 103, 129-138. doi:10.1016/j.fcr.2007.05.007

Blümmel M, Samad M, Singh OP, Amede T (2009) Opportunities and limitations of food-feed crops for livestock feeding and implications for livestock-water productivity. The Rangeland Journal 31, 207-213. doi:10.1071/RJ09005

Blümmel M, Vishala A, Ravi D, Prasad KVSV, Ramakrishna Reddy Ch, Seetharama N (2010) Multi-environmental investigations of food-feed 
trait relationships in Kharif and Rabi sorghum (Sorghum bicolor (L) Moench.) over several years of cultivars testing in India. Animal Nutrition and Feed Technology 10S, 11-21.

Blümmel M, Anandan S, Wright IA (2012) Improvement of feed resources and livestock feeding in mixed cropping systems. In 'Animal nutrition advances and development'. (Eds UR Mehra, P Singh, AK Verma) pp. 459-475. (Satish Serial Publishing House: India)

Blümmel M, Homann-Kee Tui S, Valbuena D, Duncan A, Herrero M(2013a) Biomass in crop-livestock systems in the context of the livestock revolution. Secheresse 24, 330-339.

Blümmel M, Grings EE, Erenstein O (2013b) Potential for dual-purpose maize varieties to meet changing maize demands: synthesis. Field Crops Research 153, 107-112. doi:10.1016/j.fcr.2013.10.006

Comprehensive Assessment of Water Management in Agriculture (2007) 'Water for food, water for life: a comprehensive assessment of water management in agriculture.' (Earthscan: London; and International Water Management Institute: Colombo)

Delgado C, Rosegrant M, Steinfeld H, Ehui S, Courbois C (1999) 'Livestock to 2020.' IFPRI food, agriculture and the environment discussion paper 28, Washington, DC.

Descheemaeker K, Haileslassie A, Amede T, Bossio D, Tarawali S (2010) Assessment of water productivity and entry points for improvement in mixed crop-livestock systems of the Ethiopian highlands. Advances in Animal Biosciences 1, 491-492. doi:10.1017/S204047001000110X

Descheemaeker K, Amede T, Haileslassie A, Bossio D (2011) Analysis of gaps and possible interventions for improving water productivity in crop livestock systems of Ethiopia. Advances in Experimental Agriculture 47(s1), 21-38.

Ertiro BT, Zeleke H, Friesen D, Blümmel M, Twumasi-Afriyie S (2013) Relationship between the performance of parental inbred lines and hybrids for food-feed traits in maize (Zea mays L.) in Ethiopia. Field Crops Research 153, 86-93. doi:10.1016/j.fcr.2013.02.008

FAO (1998) Crop evapotranspiration. In 'FAO irrigation and drainage paper no. 56'. (Eds R Allen, LA Pereira, D Raes, M Smith) (FAO: Rome)

FAO (2005) 'Local climate estimator (New LockClim 1.06).' (FAO: Rome)

FAO (2012) 'Balanced feeding for improving livestock productivity increase in milk production and nutrient use efficiency and decrease in methane emission, by MR Garg.' FAO animal production and health paper no. 173. (FAO: Rome)

Garg MR, Sherasiaa PL, Bhanderia PM, Phondbaa BT, Shelkea SK, Makkar HPS (2013) Effects of feeding nutritionally balanced rations on animal productivity, feed conversion efficiency, feed nitrogen use efficiency, rumen microbial protein supply, parasitic load, immunity and enteric methane emissions of milking animals under field conditions. Animal Feed Science and Technology doi:10.1016/j.anifeedsci.2012.11.005

Gebreselassie S, Peden D, Haileslassie A (2009) The factors affecting livestock water productivity: animal scale analysis using previous cattle feeding trials in Ethiopia. Rangeland Journal 31, 251-258.

Haileslassie A, Blümmel M, Murthy MVR, Samad M, Clement F, Anandan S, Sreedhar NA, Radha AV, Ishaq S (2011) Assessment of livestock feed and water nexus across mixed crop livestock system's intensification gradient: an example from the Indo-Ganga Basin. Experimental Agriculture 47, 113-132. doi:10.1017/S0014479710000815

Kelley TG, Parthasarathy Rao P, Weltzien R, Purohi ML (1996) Adoption of improved cultivars of pearl millet in arid environment: straw yield and quality considerations in western Rajasthan. Experimental Agriculture 32, 161-172. doi:10.1017/S0014479700026077

Lal R (2005) World crop residues production and implications of its use as a biofuel. Environment International 31(4), 575-584. doi:10.1016/ j.envint.2004.09.005

National Institute for Animal Nutrition and Physiology (NIANP) (2003) 'FeedBase.' (NIANP: Bangalore, India).
Nepolean T, Blümmel M, Bhasker Raj AG, Senthilvel S, Hash CT (2006) QTLs controlling stover yield and quality traits in pearl millet. International Sorghum and Millets Newsletter 47, 149-152.

Peden D, Tadesse G, Misra AK (2007) Water and livestock for human development. In 'Water for food, water for life: a comprehensive assessment of water management in agriculture'. (Ed. D Molden) (Earthscan: London; and International Water Management Institute: Colombo)

Pimentel D, Houser J, Preiss E, White O, Fang H, Mesnick L, Barsky T, Tariche S, Schreck J, Alpert S (1997) Water resources: agriculture, the environment, and society. Bioscience 47(2), 97-106. doi:10.2307/ 1313020

Prasad KVSV, Khan AA, Vellaikumar S, Devulapalli R, Ramakrishna Reddy Ch, Nigam SN, Blümmel M (2010) Observations on livestock productivity in sheep fed exclusively on haulms from ten different genotypes of groundnut. Animal Nutrition and Feed Technology 10S, 121-126.

Raes D, Geerts S, Kipkorir E, Wellens J, Sahli A (2006) Simulation of yield decline as a result of water stress with a robust soil water balance model. Agricultural Water Management 81, 335-357. doi:10.1016/ j.agwat.2005.04.006

Ramachandra KS, Taneja VK, Sampath KT, Anandan S, Angadi UB (2007) 'Livestock feed resources in different agroecosystems of India: availability requirement and their management.' (National Institute of Animal Nutrition and Physiology: Bangalore, India)

Ravi D, Khan AA, Saibutcha Rao M, Blümmel M (2013) A note on suitable laboratory stover quality traits for multidimensional maize improvement. Field Crops Research 153, 58-62. doi:10.1016/j.fcr.2013.01.013

Shah L (2007) Delivering nutrition. Power point presentation delivered at the CIGAR system wide livestock program meeting 17th September 2007 at ICRISAT, Patancheru.

Sharma K, Pattanaik AK, Anandan S, Blümmel M (2010) Food-feed crop research: a synthesis. Animal Nutrition and Feed Technology 10S, 1-10.

Singh OP, Sharma A, Singh R, Shah T (2004) Virtual water trade in dairy economy. Economic and Political Weekly 39, 3492-3497.

Steinfeld H, Gerber P, Wassenaar T, Castel V, Rosales M, de Haan C (2006) 'Livestock's long shadow.' (FAO: Rome)

Vadez V, Krishnamurthy L, Hash CT, Upadhyaya HD, Borrell AK (2011a) Yield, transpiration efficiency, and water use variations and their relationships in the sorghum reference collection. Crop and Pasture Science 62(8), 645-655. doi:10.1071/CP11007

Vadez V, Deshpande SP, Kholova J, Hammer GL, Borrell AK, Talwar HS, Hash CT (2011b) Staygreen QTL effects on water extraction and transpiration efficiency in a lysimetric system: influence of genetic background. Functional Plant Biology 38, 553-566. doi:10.1071/ FP11073

Vadez V, Kholova J, Medina S, Aparna K, Anderberg H(2014) Transpiration efficiency: new insights into an old story. Journal of Experimental Botany doi:10.1093/jxb/eru040

van Breugel P, Herrero M, van de Steeg J, Peden D (2010) Livestock water use and productivity in the Nile Basin. Ecosystems 13, 205-221. doi:10.1007/s10021-009-9311-z

Vinayan MT, Raman B, Jyothsna T, Zaidi PH, Blümmel M (2013) A note on potential candidate genomic regions with implications for maize stover fodder quality. Field Crops Research 153, 102-106. doi:10.1016/ j.fcr.2013.03.018

Zaidi PH, Vinayan MT, Blümmel M (2013) Genetic variability of tropical maize stover quality and the potential for genetic improvement of foodfeed value in India. Field Crops Research 153, 94-101. doi:10.1016/ j.fcr.2012.11.020

Zwart J, Bastiaanssen WGM (2004) Review of measured crop water productivity value for irrigated wheat, rice, cotton and maize. Agricultural Water Management 69(2), 115-133. doi:10.1016/j.agwat. 2004.04.007 